\title{
Bonfires and Barbecues: Coalition: Governance and the Politics of Quango Reform
}

Matthew Flinders, Katharine Dommett and Katherine Tonkiss

Mark Twain once noted that 'history never repeats itself, but it rhymes', and by this, he sought to capture the manner in which specific issues appear to re-emerge either within the public consciousness or onto the political agenda (or both) with a certain regularity. The electoral cycle and the existence of certain perennial social or political challenges add weight to this thesis and provide the broader context within which this article gives the first researchbased account of the Coalition Government's approach to what Nevil Johnson termed 'the quango problem'.1 The 'problem' in this sense is how to resolve the centrifugal dynamic and appointed nature of 'fringe bodies, quangos and all that' within a constitutional system that is forged upon the notion of electoral legitimacy and the centripetal logic of ministerial responsibility to Parliament.2 Even the most cursory analysis of British constitutional history in recent decades reveals the existence of a rather stark rhetoric-reality gap, whereby governments come into power committed to radically reducing the role and number of quangos (i.e. abolition) and ensuring that those which continue to exist, do so within a clear and transparent governance framework (i.e. reform). Igniting a 'bonfire of the quangos' is therefore part of the rhetorical mantra for almost any British political party in opposition. Yet, constitutional history reveals that quangos appear almost flame resistant in the sense that the rhetoric of abolition and reform has rarely been translated into reality. The comment in the House of Commons by the MP for Stoke on Trent Central, Tristram Hunt, in October 2010 that 'the much-vaunted bonfire of the quangos has turned into a clammy Sunday afternoon barbecue' therefore sought to tap into a long-running historical narrative about the use (and abuse) of quangos within British government.3

The problem with a discursive emphasis on 'bonfires' or 'barbecues' is that it over- emphasises abolition and underemphasizes reform. It also veils the manner in which many arm's-length bodies fulfil critical public tasks that are arguably best placed at some distance from elected party politicians. The aim of this article, however, is not to engage with normative arguments concerning the evolution of democratic governance but to present the results of the first detailed analysis of the Coalition Government's 'Public Bodies Reform Agenda' (PBRA) through a comparative historical analysis of previous governments. Stripped down to its core insights, this reveals five main findings:

1. The Coalition Government's approach to 'the quango problem' has been far more ambitious and farreaching than any previous government in recent political history.

2. The approach has emphasised reform rather than abolition which, in turn, reflects a great deal on the role of arm's-length bodies within modern governance.

3. The role of the Cabinet Office has been transformed from 'a hollow crown' to a strategic hub.

4. The language of 'loose-loose to tight-tight' within Whitehall captures the sense of changing relationships and the nature of reform.

5. This is generating some resentment within sponsor-departments and arm's-length bodies as the transition to a new 'tight-loose' relationship is forged.

The central argument of this article is therefore that when viewed from a historical perspective, the Coalition Government has embarked upon a distinctive and potentially far-reaching response to the 'quango conundrum'.4 This finding, and the research on which it is based, matter for at least three reasons. First and foremost, despite the extensive role of arm's-length bodies within state systems in both developed and developing systems, there has actually been relatively little published research on this topic. 5 Second, where the reform of quangos has been examined, such analyses have generally been written with very little engagement with those politicians and administrators who are actually leading the reform process. A certain naivety about the politics of reform and about the nature of the complex challenges and unintended consequences that any reform process must address is generally over- looked in favour of a focus on abolition borne from an implicit assumption that quangos are 'bad'. 6 The basis of this article in research conducted in association with (but independently of ) the Cabinet Office-with 
over 70 interviews and a number of practitioner working groups and seminars-provides an account of the dynamics of reform from within the system. Finally, although studies exist of specific arm's-length bodies, of discrete historical periods or of quangos in certain countries, there is a dearth of literature that adopts an explicitly comparative perspective, either geographically or historically.7

As a result, this article adopts a four-part structure (see Table 1 ) in order to compare the approach of the Coalition Government since May 2010 to the pattern of reform processes that have preceded it. The first three sections provide the historical foundations for the original empirical research on which this article is based. Their aim is not to provide an exhaustive historical account but simply to identify the existence of a rhetoric-reality gap, whereby opposition parties consistently promised far-reaching reform in opposition but quickly reneged upon such commitments once in office. The fourth and most substantial section then examines the Coalition Government's PBRA and suggests that the historical pattern has to some degree been broken. The rhetoric of quango reform has been matched by a reality of reform that has emphasized a need to improve public accountability and internal control. The final section then reflects upon the broader implications of this finding for both historical and comparative research.

Table 1 A political history of the politics of quangos and reform: four phases.

\begin{tabular}{|c|c|c|c|c|}
\hline Period & Epithet & $\begin{array}{l}\text { Key } \\
\text { government/parlia } \\
\text { mentary reports }\end{array}$ & Think tank reports & Key academic texts \\
\hline The long view & Mad empiricism & $\begin{array}{l}\text { Anderson Report, } \\
\text { 1945Bowan Report } \\
1978\end{array}$ & $\begin{array}{l}\text { Philip Holland and } \\
\text { t Michael Fallon, } \\
\text { The Quango } \\
\text { Explosion, } \\
\text { 1978Philip Holland, } \\
\text { Quango, Quango, } \\
\text { Quango, } \\
\text { 1979Philip Holland, } \\
\text { The Govemance of } \\
\text { Quangos, } 1981\end{array}$ & $\begin{array}{l}\text { Toulmin Smith, } \\
\text { Government by } \\
\text { Commission: } \\
\text { Dangerous and } \\
\text {, Permicious, } 1849 \\
\text { Henry Parris, } \\
\text { Constitutional } \\
\text {, Bureaucracy, } 1969 \\
\text { f }\end{array}$ \\
\hline $\begin{array}{l}\text { The Conservatives } \\
\text { 1979-97 }\end{array}$ & s, Cosmetic pruning & $\begin{array}{l}\text { Cm. } 7797 \text {, Pliatzky } \\
\text { Report, } 1980 \mathrm{Cm} \text {. } \\
\text { 3557, The } \\
\text { Governance of } \\
\text { Public Bodies: A } \\
\text { Progress Report, } \\
1997\end{array}$ & $\begin{array}{l}\text { J. Stewart, } \\
\text { Reforming the New } \\
\text { Magistracy. } \\
\text { Commission for } \\
\text { Local Democracy, } \\
1994 \text { Weir, Stuart } \\
\text { and Wendy Hall, } \\
\text { EGO-Trip, 1994, } \\
\text { London: Charter } 88\end{array}$ & $\begin{array}{l}\text { Chris Skelcher, } \\
\text { w The Appointed } \\
\text { State, } 1998 \\
8\end{array}$ \\
\hline $\begin{array}{l}\text { New Labour, } \\
\text { 1997-2010 }\end{array}$ & $\begin{array}{l}\text { Hyper- } \\
\text { institutionalism }\end{array}$ & $\begin{array}{l}\text { Cabinet Office, } \\
\text { Quangos: Opening } \\
\text { the Doors, } 1998 \\
\text { Cabinet office, } \\
\text { Better Government } \\
\text { Services, } 2002\end{array}$ & $\begin{array}{l}\text { Centre for Policy } \\
\text { Studies, School } \\
\text { Quangos: A } \\
\text { Blueprint for } \\
\text { t Abolition and } \\
\text { Reform, 2000Adam } \\
\text { Smith Institute, } \\
\text { Hunting of the } \\
\text { Quango, } 2009\end{array}$ & $\begin{array}{l}\text { Matthew Flinders, } \\
\text { Delegated } \\
\text { Governance and } \\
\text { the British State, } \\
2008 \\
\text { n }\end{array}$ \\
\hline $\begin{array}{l}\text { Conservative-Libe } \\
\text { al Democrat }\end{array}$ & $\begin{array}{l}\text { rThe centre strikes } \\
\text { back }\end{array}$ & $\begin{array}{l}\text { Public } \\
\text { Administration }\end{array}$ & $\begin{array}{l}\text { Institute for } \\
\text { Government, Read }\end{array}$ & $\begin{array}{l}\text { Matthew Flinders } \\
d \text { and Chris }\end{array}$ \\
\hline Coalition, 2010- & & $\begin{array}{l}\text { Select Committee } \\
\text { (PASC), Smaller } \\
\text { Government: } \\
\text { Shrinking the } \\
\text { Quango State, } \\
2010\end{array}$ & $\begin{array}{l}\text { Before Burning, } \\
\text { 2010Institute for } \\
\text { Government, It } \\
\text { Takes Two, } 2012\end{array}$ & $\begin{array}{l}\text { Skelcher, Shrinking } \\
\text { the Quango State, } \\
\text { Public Policy and } \\
\text { Management, } \\
\text { 2012, 32(5), } \\
327-334\end{array}$ \\
\hline
\end{tabular}




\section{The Long View}

As W.H. Greenleaf's The British Political Tradition illustrates in great detail, the embryonic British state emerged from the sixteenth century onwards in an extemporized fashion. It was a process characterized by 'incoherent arbitrariness' in which systemic logic, explicit theory and grand planning were eschewed in favour of piecemeal ad hoc adaptation. This led Herman Finer to note that, 'the striking feature of English administrative evolution is the small amount of conscious or at least formal thought bestowed upon it until the end of the eighteenth century'.8 Prior to the nineteenth century, the King was generally reluctant to vest too much power in one person, and Crownappointed multi-member independent boards or commissions formed the dominant administrative unit. The Sewers Commission (established 1540), Bankruptcy Commission (1570), Board of Excise (1643) and Board of Control (1784) provide examples of such administrative innovations but as early as the end of the seventeenth century, the lack of any clear form of democratic accountability was emerging as a matter of debate. 9 In 1694, for example, John Somers, then Attorney General, wrote to King William III, 'There is one thing necessary for carrying on your service which was extremely wanting in those two commissions (the Board of Customs and the Board of Excise); that there should be somebody of them who might upon all occasions give a satisfactory account in the House of Commons of what related to their proper business'.

After the 1832 Reform Act, MPs felt particularly empowered by the extension of the franchise to play a greater role in overseeing the bureaucracy, while the demands of the industrial revolution called for a more coherent and professional public service. Works such as Toulmin Smith's Government by Commission: Dangerous and Pernicious (1849) and Walter Bagehot's The English Constitution (1867) attacked the weakness of ' ... . conducting the administration of a public department by an independent unsheltered authority' and led to the emergence of the ministerial department as the main administrative unit within British government.10 As a result, during the second half of the nineteenth century, a number of boards were abolished and their functions taken over by ministerial departments. Where independent boards continued to operate without a minister, they did so under the auspices of a nominated minister, meaning that they frequently found their independence curtailed and encountered a far higher degree of ministerial involvement in their day-to-day activity. 11 Critically, it was at this point in Britain's constitutional history that the institution of the ministerial department and the convention of ministerial responsibility to Parliament became ingrained (in principle if not in practice). 12 Towards the end of the century, many commentators believed that the demise of appointed boards had been sealed as parliamentary appreciation of the virtues of individual ministerial responsibility grew; ministerial departments became better equipped to take on new functions and the weight of tradition to invest new functions to independent commissions waned.

The rhetoric of ministerial responsibility and ministerial departments, however, did not quite capture the reality of the bureaucratic accretion and sedimentation of the British state as it had and was evolving. Despite the creation of several ministerial departments and the abolition of some boards, the creation of new 'non-departmental organizations' had, as Henry Parris's Constitutional Bureaucracy (1969) illustrates, continued apace throughout the nineteenth century. Furthermore, many feared that a new pool of patronage had been created beyond the civil service (with concomitant concerns regarding cronyism, corruption and nepotism).13 The 'long view' therefore reveals that the 'quango problem' has deep roots in British political history. It also reveals the manner in which the British political tradition emphasized flexibility and ministerial capacity over constitutional rigidity and rules. The 'quango problem' may well have been a problem for those who sought to understand the British state or to hold certain individuals or organization to account towards the end of the nineteenth century but for ministers, (and their officials) they proved not so much a problem as a solution to an increasing range of pressing social challenges.

In 1918, the Haldane Commission uncovered 'obscurity and confusion in executive Government' and that the growth of non-departmental bodies was 'obviously unsatisfactory'.14 It therefore re-emphasized the ideal of the ministerial department and warned against the creation of independent boards beyond the departmental model 'immune from ordinary parliamentary criticism' but as Street remarks 'Generally speaking ... the sentence of the Haldane Committee was not carried out ... in the decades that followed when there was a proliferation of quasi-government bodies'.15 Concern about the 'quango problem' therefore offers a thread that runs throughout the first half of the 
nineteenth century. In 1929, for example, Lord Hewart's The New Despotism provided a general criticism of delegation; in 1936, William Robson suggested 'We are, it would seem, drifting towards something not far removed from what may be called 'Government by Commission",16 and by 1941, Sir Ivor Jennings declared, 'We shall soon reach the stage where it can be seriously asked whether we have democracy when we are governed by a vast array of boards, commissions, corporations, companies, authorities and the rest whose relation to Parliament or to a local electorate is remote'.17

The Anderson Committee on the Machinery of Government reported in 1945 that '[The] number of nondepartmental organisations which have been set up at various times is enormous ... they present a variety which can certainly be described as bewildering'.18 The Committee had been unable to find even a simple list of all the public bodies that existed, let alone any coherent system or principles that could be used to explain how and why decisions had been taken regarding delegation. Anderson and his colleagues discovered no less than 16 different categories of arm's-length body, and a new seventeenth category was added by the Labour government of $1945-51$ as the boards of the nationalized industries added a new and particularly controversial layer of delegated governance.19 In the late 1960s, the Fulton Report reversed the logic of the Haldane Report and concluded 'that the possibility of considerable hiving-off should be examined, and we therefore recommend an early and thorough review of the whole question'.20 Although the Fulton Report had little direct impact in terms of delegation, it contributed to a general concern regarding the flexibility of traditional bureaucratic structures and a tendency to place new roles, responsibilities and powers at a distance from ministers. By the 1970s, a major public debate had therefore broken out concerning the number and role of quangos.

The 'quango debate' in the 1970s has been documented extensively and it is sufficient here to tease-out just three core issues.21 First, the debate was to a large extent the result of public frustration concerning the existence of a rhetoric-reality gap. Throughout the post- war decades, parties of both the left and the right had come to office with a commitment to radically reduce the number and role of quangos but had, if anything, done the opposite.22

The Labour Party embraced hiving-off as an element of a corporatist organizational design; the Conservative Party embraced hiving-off as a way of promoting quasi-market principles and encouraging specialization. 23 Both parties also took advantage of the patronage capacities offered by quangos and general elections were generally mirrored by the ebb and flow of business and trade union appointments.24 'The whole process of creating quangos has gone ahead', Nevil Johnson argued, 'in a piecemeal fashion, presenting a perfect illustration of opportunistic pragmatism at work'.25 As a result (and secondly), the quango debate was curiously free of hard data about the number of quangos that existed and their spending. 26

In order to rectify this situation, in 1975, the Civil Service Department commissioned a comprehensive survey of 'fringe bodies' (the Bowen Report); but after three years of research, there were doubts as to whether the final list of 778 bodies was anywhere near comprehensive.27 This flows into a final focus on 'ad hoccery' or a commitment to 'muddling through' as a virtue of the British constitutional tradition. As Christopher Hood et al. wrote in 1978, 'in terms of items such as agency type and classes of officials, it is often remarked that the British system appears one of "mad empiricism" governed solely by consideration of political expediency'.28 The influence of the New Right on the Conservative Party during the 1970s led the party to seize on the Bowen Report as proof of a bloated and inefficient state in need of urgent reform.29

In a series of pamphlets published by the Adam Smith Institute, the Conservative MP Phillip Holland and Michael Fallon (who would later become a Conservative MP and Minister) led a campaign against the use of quangos and what Hayek labelled 'the political machinery of para-government'. 30 Such arguments were attractive to Mrs Thatcher and the Conservative Party's 1979 General Election manifesto contained a commitment to reduce 'waste, bureaucracy and over-government'. 


\section{The Conservatives, 1979 - 97}

The Conservatives had been elected on the basis of (inter alia) 'a dogmatic anti- quango campaign'31 but the argument of this section is that pre-election rhetoric was not matched by post-election reality. Just days after the General Election in 1979, Mrs Thatcher informed the cabinet that ministers 'should consider a reduction in the quangos for which they are responsible and submit progress reports on this by 7 June'. The subsequent reports, however, tended to emphasize the need to retain rather than abolish quangos. The Scottish Office, for example, which was responsible for well over 300 public bodies, responded that the department was not willing to adopt a 'root and branch' approach to reform. One cabinet minister noted ' .. . there is not very much scope for substantial, as opposed to cosmetic, pruning'.32 Therefore although Mrs Thatcher was able to report to the House of Commons in December 1979 that 436 quangos had been identified for abolition, the vast majority of these were small advisory bodies and many had not been active for some time.33 Disappointment with the pace of reform in departments led Mrs Thatcher to commission Sir Leo Pliatzky to undertake a centrally directed 'quango review' and make proposals for reform. The subsequent report on 'Non-Departmental Bodies' (the Pliatzky Report) identified over 1500 advisory and nearly 500 executive bodies with a collective annual budget of over six billion pounds and over 250,000 staff.34

The structural impact of the Pliatzky Report was limited: only 30 executive quangos were abolished which was 'a sharp contrast between the rhetoric of quangocide and the reality of spending cuts and token sacrifices'.35 Pliatzky later reflected ' ... that such undogmatic findings should have been accepted, against the background of the dogmatic anti-quango campaign, seemed to me a satisfactory result'.36 The report did, however, emphasize longstanding concerns regarding the lack of any central register of public bodies and the absence of any central repository of knowledge regarding good governance or best practice. As a result, the Civil Service Department published an annual report on NDPBs from 1980 onwards, and new guidance documents were produced and disseminated to departments. 37

The legacy of the Pliatzky Report was also enduring for the manner in which it linked the term 'quango' with just one specific form of arm's-length body-the Non- Departmental Public Body (NDPB). The 1980s therefore witnessed complex 'quango numbers games' as the government imposed a very narrow definition of what constituted a quango while external observers, academics and opposition parties sought to incorporate a far broader range of organizational forms. Employing this narrow definition allowed the Conservative governments during the 1980s and 1990s to argue that the number of executive NDPBs had been halved (as reflected in Table 2). Yet, such claims veiled the fact that the combined annual expenditure of those NDPBs had increased from six to twenty-four billion pounds and that a vast range of new arm's-length bodies had been established but not classified as NDPBs. For example, towards the end of the 1980s, the executive agency programme established over 150 semi-autonomous agencies that were very similar in governance and form to executive NDPBs but were classified as operating within their sponsor departments and as such were omitted from the official quango count.38 


\begin{tabular}{|l|l|l|}
\hline Year & $\begin{array}{l}\text { Numb } \\
\text { er }\end{array}$ & $\begin{array}{l}\text { Total expenditure } \\
\text { fB }\end{array}$ \\
\hline 1979 & 492 & 6.15 \\
\hline 1982 & 450 & 8.33 \\
\hline 1983 & 431 & 9.94 \\
\hline 1984 & 402 & 7.28 \\
\hline 1985 & 399 & 7.77 \\
\hline 1986 & 406 & 8.24 \\
\hline 1987 & 396 & 9.10 \\
\hline 1988 & 390 & 9.45 \\
\hline 1989 & 395 & 11.87 \\
\hline 1990 & 374 & 13.08 \\
\hline 1991 & 375 & 13.75 \\
\hline 1992 & 369 & 15.41 \\
\hline 1993 & 358 & 18.33 \\
\hline 1994 & 325 & 20.84 \\
\hline 1995 & 320 & 21.42 \\
\hline 1996 & 309 & 22.40 \\
\hline 1997 & 305 & 24.13 \\
\hline
\end{tabular}

Note: No statistics are available for 1980 and 1981.

Source: Cabinet Office, Public Bodies 1998.

'Quangocratization'39 proved a particularly pronounced element of Conservative statecraft in the UK during the 1980s and 1990s. By the mid-1990s, however, the issue- attention cycle had apparently come full circle as 'the quango problem' resurfaced at the centre of accusations of unaccountable power, sleaze and corruption. The Prime Minister, John Major, responded by establishing the Committee on Standards in Public Life in 1994 and publishing the The Governance of Public Bodies: A Progress Report white paper in 1997.40 The Labour Party responded by launching a scathing attack on the growth and use of public bodies. At the 1996 party conference, Tony Blair outlined his intention to place 'the quango state in history's dustbin where it belongs'; yet, how this would be reconciled to the fact that a great number of the Labour Party's policies were underpinned by the creation of new arm's-length bodies, was unclear.

Before examining developments during 1997-2007, it is useful to conclude this section by teasing out elements of continuity or change in relation to the earlier historical sections. In terms of longevity and durability, it is clear that despite pre- election commitments and early efforts, the Conservative governments' measures were weak in terms of both abolition and reform. The politics of quangocide proved heavier on rhetoric and symbolic measures than it did on major surgery. 41 The central dynamic was one of quango growth. There is also little evidence of change in relation to the theme of 'incoherent arbitrariness' (discussed in the previous section). New bodies were created and others amalgamated but there was no determined effort to provide a coherent framework on which to base or legitimize this evolving sphere of governance. 42 Nor was there any attempt to explain why certain functions were located in specific organizational forms or how and why their respective governance frameworks differed. Continuity can also be identified in relation to the theory and practice of ministerial responsibility. The Conservative governments remained unwavering in their commitment to the theory of ministerial responsibility to Parliament despite the fact that the architects of the reforms had been very open about the practical impact of their proposals for the convention. The convention became a tool used by the executive to legitimate rejecting reforms that may have empowered the legislature vis-a'-vis the executive with a source of information that was beyond executive control. One final area where there is evidence of some change is in relation to the existence of some official register, record or catalogue of public bodies. From 1980 onwards, a register of public bodies was maintained and 
annually published although its utility was undermined by the governments' tendency to manipulate the 'quango numbers game' by defining public bodies in or out of official statistics.

\section{New Labour, 1997 - 2010}

The period 1997 - 2010 spanned three Labour governments and in relation to delegation can be divided most broadly into a period of hyper-innovation and creativity followed by a period of attempted rationalization and reform. However, it is important at this stage to emphasize that delegation was a primary theme of governance under New Labour. After 18 years in opposition, the Labour Party was intent on appearing economically competent and managerially progressive but their proposals to centralize previously delegated tasks, increase the role of politicians and the scrutiny capacity of parliament, would have contributed little to sustaining this image. Indeed, the first act of the government was to confer operational independence on the Monetary Policy Committee of the Bank of England. This is not to say that reforms were not introduced. But we are making a very explicit argument regarding the nature of British governance under 'New' Labour, particularly about its failure to underpin the widespread use of delegation within a principled or transparent governing framework.43

In November 1997, the government published a green paper-Opening up Quangos-in which it announced its intention to review all NDPBs. A distinctive quality of this document was its balanced tone which was far-removed from the 'anti- quango' polemics that had dominated the discourse and publications of Labour politicians during the mid-1990s. The document not only set out in great detail the benefits of delegation but also signalled that a 'bonfire of quangos' was not about to take place: ' ... many (public bodies) will continue to exist, either as at present or in a revised or amalgamated form'.44 Six months later, the government set out its main reforms for the openness and transparency of public bodies in Quangos: Opening the Doors.45 The proposals were notable for their frailty rather than their strength and included the following elements:

1. NDPBs should hold annual open public meetings, where practicable and appropriate.

2. Where practicable, NDPBs should release summary reports of meetings.

3. NDPBs should invite evidence from members of the public to discuss matters of public concern

4. NDPBs should aim to consult their users on a wide range of issues by means of questionnaires, public meetings or other forms of consultation.

5. Executive NDPBs and Advisory NDPBs that have direct dealings with members of the public should be brought within the jurisdiction of the Parliamentary Ombudsman.

6. The Government proposes to invite parliamentary select committees to take a more active role in scrutinizing the work of NDPBs.

7. All advisory and executive NDPBs should produce and make publicly available Annual Reports.

The Labour government's initial response to 'the quango problem' was therefore notable for two key features. Firstly, the government's approach was, as PASC concluded, 'unambitious, piecemeal and ad hoc'.46 The failure of the government to include all forms of arm's-length bodies within its approach, while at the same time relying on 'soft' guidance advice for NDPBs instead of 'hard' statutory controls governing open meetings and consultations, attracted criticism. Second, in historical terms, the emphasis of the new government on explaining why quangos actually played an important role in public life and suggesting that some new bodies might actually need to be created and that select committees might offer a cure to 'the quango problem' by increasing their levels of scrutiny, was an almost word-for-word replication of the position adopted by the incoming Conservative government in 1979. What made this position more problematic was the consistent refusal by the government to accept any reforms that would have imposed greater consistency on the sphere of delegated governance or would have rationalized the accountability frameworks in order to make select committee scrutiny easier.47

At first glance, Table 3 appears to suggest that New Labour did in fact deliver on its pre-election commitments to 'end the quango state'. The number of NDPBs had fallen from 305 in 1997 to 211 in 2006 . However, this baseline statistic hides a number of issues. The reduction in the number of NDPBs was achieved as a result of devolution to 
Scotland and Wales. The reduction did not stem from abolitions but from a transfer of responsibilities from the national to sub-national level.48 Moreover, as devolution reduced the number of executive NDPBs operating at national level by around a third, it might be expected that this would be reflected in a significant reduction in the annual expenditure, but as Table 3 shows, there is no clear correlation. Apart from a temporary reduction in 2002, the combined expenditure figures continued to increase. At the very least, this suggests that the Labour government did not seek to reverse the role and resources of public bodies as the sphere of delegated governance actually grew far more rapidly during this period, but much of this growth did take place off-stage (i.e. tasks were delegated to public bodies not formally designated as NDPBs).

Table 3 Executive NDPBs, 1997 - 2009.

\begin{tabular}{|l|l|l|}
\hline Year & Number & Expenditure $(\mathrm{fB})$ \\
\hline 1997 & 305 & 22.40 \\
\hline 1998 & 304 & 24.13 \\
\hline 1999 & 306 & 23.37 \\
\hline 2000 & 297 & 23.90 \\
\hline 2001 & 276 & 25.17 \\
\hline 2002 & 192 & $20.77^{\mathrm{a}}$ \\
\hline 2003 & 206 & 25.54 \\
\hline 2004 & 210 & 29.48 \\
\hline 2005 & 211 & 32.87 \\
\hline 2006 & 199 & 36.75 \\
\hline 2007 & 203 & 37.02 \\
\hline 2008 & 198 & 42.99 \\
\hline 2009 & 192 & 46.49 \\
\hline
\end{tabular}

Note: The Government stopped producing annual statistics from 2009.

Source: Cabinet Office, Public Bodies 2009.

${ }^{\mathrm{a}}$ This sudden decline in numbers and spend was largely due to devolution.

The extent of this 'off-stage' growth has been documented in some detail elsewhere, and it is sufficient for the purposes of this section to note that Flinders identified at least $300 \mathrm{arm}$ 's-length bodies that had been created by New Labour but were not included within any official documents or registers. 49 Some of these organizations represented the latest incarnation of long-devolved functions; the Independent Police Complaints Commission, for example, was established in 2002 but similar functions had been previously conducted by the Police Complaints Authority (1984 - 2002) and Police Complaints Board (1976 - 84). However, a significant number formed central components of the Labour government's flagship policies (e.g. New Opportunities Fund, Youth Justice Board, Low Pay Commission). By the beginning of the 2001-05 Parliament, the government appeared to be suffering from 'institutionalitis' - the tendency to respond to every problem by setting up another organization. $50 \mathrm{In}$ the health sector, for example, the disagreement between the Chancellor of the Exchequer and the Health Secretary over foundation hospitals led to the creation of the Office of the Independent Regulator for NHS Foundation Hospitals. This hyper-institution- alism was not matched by the creation of a transparent framework, statement of principles or comprehensive account of all the public bodies that existed, let alone why they had been established or why a specific organizational form has been adopted in each case. It is exactly this clarity and consistency that PASC was demanding in its 1998 report and in its Mapping the Quango State report of 2001.51

These issues were, however, brought to the fore in July 2002 with the publication of Better Government Services by the PM's Office for Public Sector Reform which highlighted (inter alia) 'irrational organisational design', 'ambiguous governance frameworks' and 'the dangers of unregulated fragmentation and complexity'. The report also suggested that departmental control and co-ordination mechanisms had become so weak in some areas that 'some agencies had become disconnected from their departments' to the extent that they had assumed 'orphan status'.52 When the Better Regulation Task Force echoed these complaints in October 2003 and the Gershon Review suggested that 
significant efficiency savings could be accrued through the amalgamation and abolition of public bodies in July 2004, the government entered a clear rationalization and consolidation phase. For example, the Haskins Review on rural policy delivery led to the abolition of several bodies and the amalgamation of several others into a new organization, Natural England;53 and in the Department of Health, the Warner Review saw 32 'arm's-length bodies' reformed into just 12.54

Although it is possible to portray $2003-07$ as a period of rationalization, it is important to distinguish it from a centralizing phase. As the Better Government Services report of 2002 emphasized, governing at a distance remained the central dynamic of the public reform agenda. The sphere of delegated governance was reformed into a slightly smaller number of public bodies with broader responsibilities. It is also true that the rationalization phase was not wholly successful. In several areas, the government's plans to abolish specific bodies were abandoned due to parliamentary or interest group objections. For example, the planned merger of the five HM Inspectorates (prisons, police, probation, etc.) into one Justice and Community Safety Inspectorate were not taken forward after the Lords voted against the Police and Justice Bill 2006, and the Hampton Report led to 19 (as opposed to the 31 identified in the report) being amalgamated into seven bodies. It is therefore difficult to avoid the conclusion that overall 'the quango problem' became, if anything, more rather than less severe under New Labour.

However, towards the end of the 2005 - 10 Parliament, the impact of the global financial crisis on public spending made far-reaching reform of some manner necessary (if not inevitable). In July 2009, the Chief Secretary, Liam Byrne, launched a cross-Whitehall review of arm's-length bodies with a view to delivering significant efficiency savings through abolitions and mergers. The result was a plan to save over 500 million pounds by abolishing over 120 arm's-length bodies - should the Labour Party win the forthcoming General Election. 55 The response of the Conservative Party on this topic was, however, unexpected. 'It would be far too simplistic for me to stand here and announce some kind of "Bonfire of the Quangos"' David Cameron stated in a July 2009 speech. 'People have heard that kind of talk many times before, and seen little to show for it'. He went on to emphasize that,

We need a more sophisticated approach. Yes we need to reduce the number, size, scope and influence of quangos. But we also need to recognize that there are circumstances where functions of the state do need to be carried out independently of elected politicians.56

The contours and impact of this more sophisticated approach to 'the quango problem' forms the focus of the next and most substantive section of this article.

\section{Coalition Governance, 2010 -}

This article has so far identified a historical pattern whereby the pre-election rhetoric surrounding what Hood labels 'quangocide' has never been matched by far-reaching abolition or reform (discussed above). This has created a relatively clear issue-attention cycle bound by a rhetoric-reality gap. The argument of this section is that the Coalition Government has, to some extent, broken this cycle. Since May 2010, a far-reaching reform agenda has been implemented that cannot be dismissed as 'cosmetic' in form or nature. Indeed, one of the critical elements of this agenda was an attempt not to over-inflate public and political expectations vis-a'-vis quangos but to promote a more sophisticated narrative about reform rather than abolition. As the Institute for Government argued in its July 2010 report, 57 the solution to 'the quango problem' was unlikely to involve widespread abolition but might more profitably focus on the implementation of a clearer and more transparent governance framework.58

Therefore, although the issue of reforming quangos was a feature of both the Conservative Party's and the Liberal Democrats' election manifestos-and the subsequent coalition agreement contained a commitment to 'reducing the number and cost of quangos' - the approach of the coalition was notable for the manner in which it rested on the application of four key questions.59

The first 'existential question' focused on whether the role fulfilled by the body was actually still needed. If the answer was negative, the body could simply be abolished; but if it was positive, the question then shifted to the 
appropriate organizational form that should have responsibility for that function. Under the coalition, NDPBs would only be maintained where:

1. they undertook a precise technical operation;

2. there was a need for impartial decisions to be made about the distribution of public monies; or

3. there was a need for facts to be transparently determined, independent of political interference.

In many ways, the Coalition Government was re-emphasizing the Haldane principle that ministerial departments of state, headed by politicians who are directly accountable to Parliament, should be the default organizational unit. The aim of the 'Public Bodies Reform Programme' (PBRP), as the Minister for the Cabinet Office, Francis Maude, explained to the House of Commons in June 2010, is to save money and increase democratic accountability.60 In order to examine the PBRP in more detail, it is useful to distinguish between the initial 'Review/Abolition' phase and the subsequent 'Reform/Governance' phase.

\section{Review/Abolition}

On 10 June 2010, the Coalition Government launched a fundamental review of all public bodies. The complete lack of any reliable central lists or registers of arm's-length bodies-irrespective of their specific organizational formmade this a major undertaking. Although excluding some organizational categories (notably executive agencies and health bodies), the 2010 review (hereon referred to as the Maude Review) was undoubtedly the most comprehensive analysis of public bodies in the UK for several decades.61 It identified 679 NDPBs and 222 other statutory bodies (i.e. non- minsterial departments, public corporations and 'floating bodies') and its recommendations were far-reaching when compared against previous reform agendas. Whereas the Pliatzky Review of 1980 recommended a 12 per cent reduction in the number of public bodies, the Maude Review targeted over a third of all bodies (more specifically 159 advisory NDPBs, 78 executive NDPBs, 6 tribunal bodies and 19 'other' bodies). 62 The fate of a further 40 bodies remained 'under consideration'.63

A Public Bodies Bill was brought forward as the main vehicle for implementing these measures, and although the government was forced to make a number of concessions, the Public Bodies Act 2011 received Royal Assent on 14 December 2011.64 Twelve months later, Public Bodies 2012 (re-published after a three-year hiatus) reported that more than 130 bodies had been abolished and more than 150 merged into fewer than 70 (an overall current reduction of around 220). Of the bodies already reformed, 38 have occurred using the Public Bodies Act 2011, with many others scheduled for change by this means in the coming year. In line with this progress, the government is due to have completed around 70 per cent of all proposed abolitions by the end of financial year 2012-13.65 Public Bodies 2012 therefore reports a sudden fall in both the number and expenditure of bodies (Table 4) that, in turn, highlight five elements of the PBRP.

Table 4 Executive NDPBs, $1997-2012$.

\begin{tabular}{|l|l|l|}
\hline Year & Number & Expenditure $(\mathrm{fB})$ \\
\hline 2004 & 210 & 29.48 \\
\hline 2005 & 211 & 32.87 \\
\hline 2006 & 199 & 36.75 \\
\hline 2007 & 203 & 37.02 \\
\hline 2008 & 198 & 42.99 \\
\hline 2009 & 192 & 46.49 \\
\hline 2012 & 185 & $31.20^{\text {a }}$ \\
\hline
\end{tabular}

Note: The government stopped producing annual statistics from 2009.

${ }^{\mathrm{a}}$ This includes $£ 25.7$ billion of total direct government funding with the remainder derived through fees, charges, etc.

First and foremost, the impressive claims about abolishing quangos have generally been achieved by abolishing or merging relatively small advisory bodies (e.g. Agricultural Dwelling House Advisory Committees, Agricultural Wages 
Committees, Court Boards, Advisory Committees on Justices of the Peace and Drainage Boards). Moreover, some of these advisory NDPBs - our research suggests around 40-will immediately by reincarnated as advisory 'committees of experts' by departments. Second, the PBRP has generally involved the transfer of functions between organizational forms rather than the abolition of functions in toto (i.e. a process of 'bureau-shuffling'). In many cases, the functions have been transferred to an alternative form of arm's length body: nine new executive agencies have been created (i.e. hived-in rather than hived-out but still at arm's length) and a significant number of functions (22) have been transferred to 'other bodies'. For example, the British Waterways Board was abolished, and in its place, the Canal and River Trust, a charity, was created to maintain its functions. Similarly, the Community Development Foundation was declassified as an NDPB and reformed as a 'social enterprise' to again deliver functions through alternative organizational forms. This flows into our third theme and a focus on efficiency savings.

In opposition, the Conservative Party had claimed that 'cutting quango bureaucracy' would save at least one billion pounds a year and as part of the Coalition Government had claimed that the PBRP would deliver efficiency savings of at least $£ 2.6$ billion by the 2015 General Election.66 The National Audit Office (NAO), however, has published 'significant reservations' about whether such large savings will actually be delivered.67 The NAO found that the costs of reform (e.g. redundancy payments, contractual liabilities, etc.) had been severely underestimated by departments and may total up to $f 1$ billion. The Public Accounts Committee scrutinized the government's claims and also voiced 'substantial concerns about the robustness of the Government's claimed $£ 2.6$ billion administrative savings figure' and demanded that the government come forward with a clear 'Benefits Realisation Framework'.68 Although the coalition is yet to publish a comprehensive and auditable framework, what is arguably more important is the manner in which the majority of bodies, and especially the larger executive bodies, have not been abolished. Indeed, as the NAO made clear in its Reorganising Central Government Bodies report of April 2012, at least $£ 43.2$ billion of spending remains at arm's-length from the government. Although this figure is contested by the government (who put the figure at closer to $f 31.2$ billion), the simple fact is that 'the quango problem' has not been resolved through a simple process of abolitions, axes, bonfires or quangocide.

Indeed, between May 2010 and January 2013, the coalition established no less than 22 new arm's-length bodies (approximately one a month) of which some are NDPBs, like the Social Mobility and Child Poverty Commission, Office for Budgetary Responsibility and Independent Commission for Aid Impact, whereas the classification of others, such as the Office of Tax Simplification and the Major Projects Authority, remains ambiguous. Although not included in Public Bodies 2012, the creation of the NHS Commissioning Board (now called 'NHS England') as an executive NDPB in October 2012 with an annual budget in excess of $£ 80$ billion (twice as much as all the other quangos put together), the abolition of Regional Development Agencies to make way for Local Economic Partnerships (a new local form of quango) and similarly the creation of 'Clinical Commissioning Groups' at a local level to replace NHS Primary Care Trusts, underlines the claim that the significance of the coalition's approach lies not so much in abolition but in the reform of the internal governance and control of public bodies. This is the topic of the next sub-section.

\section{'Reform/Governance'}

The significance of the Coalition Government's approach to 'the quango problem' lies in the creation of a far clearer and tighter internal governance framework. Almost exactly 10 years before the Coalition Government came to power, a report by the Prime Minister's Office for Public Sector Reform had highlighted that irrational organizational design, ambiguous governance frameworks and unregulated fragmentation and complexity had grown beyond ministerial departments.69 This was a criticism that would surface regularly during the subsequent decade and explains why the Read Before Burning report by the Institute for Government sought to shift the debate away from abolition and towards a reform agenda that would tighten the control frameworks within which quangos operated.70 The most significant finding of the research on which this article is based is therefore a shift in governing relationships that is frequently characterized by officials as a move from a 'loose-loose' to 'tight-tight' relationship between arm's-length bodies and their parent departments; the former recognizing the 'orphan status' relationship and the existence of both a policy framework that offered high-levels of discretion and an internal 
governance structure that lacked controls, and the latter intended to signal the application of a far tighter policy framework alongside the implementation of tighter day-to-day control mechanisms.

In relation to the PBRP, the transition to a 'tight-tight' relationship has involved at least five inter-related measures. The first was the fundamental review of all public bodies and the generation of reliable data about the number of arm's-length bodies that are actually sponsored by each department. This led, as has been noted, to the abolition, merger or reclassification of a number of bodies in order to streamline the delivery chain in many policy areas. The second element, however, was a commitment to 'ensuring the legacy of reform through regular, robust review and improvement' so that even where bodies had been retained under the initial Maude Review, they would now be subject to a triennial review process that would question their continued existence. The three-year rolling programme of reviews includes all NDPBs and in many ways recreates the quinquennial review process that was abolished in the wake of the 2002 Alexander Report. During the first two years, 78 bodies have undergone triennial review and 38 have been subject to substantial organizational change (although this includes change to the 35 Probation Trusts reviewed together). 71 Yet with 280 NDPBs exempt from review until $2014-16$ the capacity of triennials to deliver ongoing reform has not yet been fully tested.72

The third element of the 'tight-tight' relationship focuses on financial controls. In his 2009 'Bonfire of the Quangos' speech, David Cameron argued that 'proper public spending control means proper control of quango spending and proper control of quango spending has to start at the top'.73 It is unsurprising therefore that when it came to power, the Coalition Government quickly introduced a raft of spending controls right across central government-including public bodies. While initially intended as temporary, to send a message that the government was serious about reducing public sector spending, these controls have become permanent and have significantly impacted on the actions of public bodies: covering spending on advertising, consultancy, IT, procurement and the hiring of new staff.74 In addition, the Cabinet Office and Treasury have increased the amount of data that public bodies must regularly provide, including the publication of all salaries over $£ 150,000$ and all spending over $£ 25,000$ (all monitored by a new Public Sector Transparency Board).75

At a broader level, the introduction of 'Whole of Government Accounts', a consolidated set of financial statements for around 1500 organizations across the public sector, will provide new levels of transparency, delivering comparable accounts by which to assess government organizations. Additionally, as part of the 'Clear Line of Sight (Alignment)' project, the expenditure of NDPBs is now incorporated into the Estimates and Resource Accounts of sponsoring departments. While these tighter controls remain a source of contention amongst both the management of public bodies and their sponsors, with some viewing them as restricting public bodies' ability to deliver effective and efficient functions, they represent a key way in which government has developed a tighter relationship with public bodies.

The fourth feature of the new internal governance structure focuses on departmental sponsorship and the skills that allow effective relationships to develop. The history of Whitehall includes a large number of official reviews into the governance of quangos which all emphasize the issue of departmental sponsorship as a major skills-gap,76 but despite this, the issue has received little attention. As Box 1 illustrates, since May 2010, the issue of sponsorship in terms of skills, training and support has been the focus of sustained reform within Whitehall. The establishment of cross-governmental support and skills development networks flows into our fifth and final reform theme-enhanced central strategic capacity. 
1. Cross-Whitehall Sponsorship Network established (meeting monthly and led by the Ministry of Justice) to share examples of best practice and discuss principles of good sponsorship.

2. Sponsorship Competency Framework developed for all civil servants working in a sponsorship role.

3. Sponsorship now recognized as a formal professional specialism within the Civil Service (https://civilservicelearning.civilservice.gov.uk/specialism-new/ sponsor).

4. Cross-Government Sponsorship Champion appointed (Catherine Lee) to raise awareness of the specialism, build partnerships between departments and public bodies and promote learning and development.

5. Training units now hosted on the Civil Service Learning e-platform.

6. Sponsors Induction Pack developed and all central guidance documentation revised and re-issued.

7. Document sharing depository and message board established (www.collaborate. gsi.gov.uk).

In the run up to the 2010 General Election, the Agencies and Public Bodies Team in the Cabinet Office consisted of just one full time and one part-time member of staff- a lack of central strategic capacity which was described by Flinders as 'the hollow crown'.77 Since 2010, however, the size, role and capacity of the Cabinet Office has increased significantly with the Public Bodies Team increasing to 15 full-time policy adviser posts. The team has been actively leading the implementation of the PBRP with departments, convening a public bodies reform 'working group' with representatives from departments across Whitehall and a strategy board with more senior representation. The team has also expanded its role in overseeing the governance of public bodies through the controls framework discussed previously, increasing sponsorship capacity within sponsor departments and generally playing a far more proactive role in setting cross-cutting policy in public bodies. Since January 2013, the Public Bodies Team also sits within a broader Transformation Cluster that contains a range of units, such as the Mutuals Team and the Commercial Models Team, that are designed to support and drive forward the PBRP.

From a situation where many bodies had assumed 'orphan status', the common criticism from the chairs and chief executives of public bodies is now that the Cabinet Office is too controlling to the point that micro-management risks undermining the arm's-length relationship.78 As one official based within an NDPB argued, 'It's gone from an arm's-length relationship to more like an arm-lock!' (Interview, May 2013). This situation was recognized by a senior civil servant at an event on the future of arm's-length bodies in July 2012 when they described the changed relationship between departments and NDPBs as the imposition of 'the tourniquet model' before going on to remark that 'we all know what happens if a tourniquet is too tight or is kept on for too long ... The arm drops off!' This is a powerful metaphor that relates to the fact that the Coalition Government's tighter controls framework was initially announced as a temporary measure but in June 2012, it was announced that 'the controls have been extended permanently as they support a new more business-like way of working' (Cabinet Office, 2013: 6). As one official within the Cabinet Office put it 'Tight-tight is the new permanent!' (Interview, November 2012). The optimum relationship would therefore be one that might be characterized as 'tight-loose' in the sense that public bodies operate within a very clear policy framework (the 'tight' element) but then enjoy high levels of day-to-day autonomy in relation to how to deliver that policy (the 'loose' element). But what really matters about the research presented in this article is the manner in which it points towards the 'filling-in' of the 'hollowing-out' under the Coalition Government since 2010.

\section{The Future of the State}

This article has examined 'the quango problem' from a historical perspective. It has argued that although many previous governments exhibited a rhetoric-reality gap in relation to quango-reform, the post-2010 Coalition Government have adopted a more coherent and potentially significant reform agenda that has focused on reform rather than abolition. We have not therefore (to return to Hood's phraseology) argued that 'major surgery' has occurred in the quango landscape or that recent reforms can be dismissed as 'cosmetic pruning'.79 The aim of this concluding section is to step-back and look at the broader implications of the historical narrative provided by this article. 
To what degree does the coalition's PBRP represent a break with the British political tradition? Or, put slightly differently, what evidence is there that the government has been willing to forego the 'mad empiricism' that formed a central element of the statecraft of previous British governments? To answer this question, it is useful to distinguish between 'mega-constitutional change', on the one hand, and 'constitutional change', on the other. Megaconstitutional change or reform involves an attempt to alter the fundamental principles of a polity. 80 Megaconstitutional politics therefore focuses on debates concerning the basic foundations, framework or 'rules of the game' that, in turn, set certain parameters-a form of constitutional bounded rationality-within which meso and micro-constitutional arguments would be based. The argument this framework allows us to develop is that the Coalition Government has not delivered a break with the British political tradition because it has refused to engage with a more fundamental reform of the state that would have limited its future flexibility. More specifically, the Institute for Government's programme for radical reform and the introduction of a completely new taxonomy for all arm's-length bodies-which was supported in principle by PASC, who called on the government to use the triennial reviews process to 're-examine the proper governance arrangements for each public body and place them in a new simplified taxonomy'81-was rejected by a government who seemed unwilling to fetter its capacity for bureaucratic creativity and change. The government's subsequent reforms have therefore been implemented within a powerhoarding system that is unwilling to limit its own discretion. However, within this mega-constitutional framework, it is clear that the approach of the Coalition Government has been distinctive in the manner in which it has sought to impose greater control over certain forms of delegated governance.

This emphasis on certain forms of delegated governance not only highlights a fault-line in the Coalition's approach but also underpins a more fundamental reflection on the changing nature or structure of the modern state. That is, the Coalition Government, like its predecessors for at least 30 years, has implicitly accepted what is termed 'the hub model of government' as the most appropriate organizational form. In this model, the ministerial department forms little more than a policy-making core that directs and commissions the activities of a wide-range of delivery or regulatory bodies in an almost perfect form of 'steering but not rowing'. The implicit nature of this design logic is revealed in the government's introduction to Public Bodies 2012 and the commitment to create 'a slimmed-down and more efficient centre that enables and empowers' .82

The interesting element of this hub-and-spoke logic is the manner in which the Coalition Government's approach to 'the quango problem' has been somewhat myopic, even inconsistent, in the sense that its focus has been on one species of arm's-length body (the NDPB) while other equally important species (e.g. public corporations, executive agencies, special health authorities, non-ministerial departments, etc.) have received far less attention. 83 Moreover, the centripetal logic of the PBRP seems to grate against the centrifugal logic of the Civil Service Reform Agenda with its emphasis on creating new forms of 'alternative service delivery providers'. The risk is that reforms to increase the transparency and control of NDPBs are quickly offset by the rapid creation of increasingly complex social enterprises, mutuals, government-owned-companies, outsourcing mechanisms and public-private partnerships-all forms of arm's-length body. It is for exactly this reason that this article, for all the Coalition Government's reforms, is unlikely to be the last analysis of 'the quango problem'.

Notes

Note: No statistics are available for 1980 and 1981.

Source: Cabinet Office, Public Bodies 1998.

Note: The Government stopped producing annual statistics from 2009.

Source: Cabinet Office, Public Bodies 2009.

a This sudden decline in numbers and spend was largely due to devolution.

Note: The government stopped producing annual statistics from 2009.

a This includes $\mathrm{f} 25.7$ billion of total direct government funding with the remainder derived through fees, charges, etc.

[1] Johnson, 'Quangos and the Structure'.

[2] Chester, 'Fringe Bodies, Quangos and All That'.

[3] HC 515, Public Bodies Reform. 
[4] Rutter and Nash, 'Quango Conundrum'.

[5] Bouckaert and Peters, 'What is Available and What is Missing'.

[6] For a detailed discussion on this topic see Flinders, Delegated Governance and the British State. [7] Exceptions to this point include Talbot and Pollitt, Unbundled Government. A major strand of the research on which this article is based will focus on international and comparative reform agendas. See Skelcher, 'Arm's Length Bodies'.

[8] Finer, Theory and Practice, 1281.

[9] Quoted in Parris, Constitutional Bureaucracy, 34.

[10] See Craig, 'Whitehall Through the Centuries'; Willson, 'Ministries and Boards'; and Schaffer, 'Idea of the Ministerial Department'.

[11] Hanham, Nineteenth Century Constitution.

[12] See Flinders, 'Enduring Centrality'.

[13] Hoogenboom, Outlawing the Spoils and Chapman, Civil Service Commission.

[14] HM Government, Haldane Report.

[15] Street, 'Quasi-Government Bodies Since 1918', 158.

[16] Robson, 'Public Service', 192.

[17] Jennings, British Constitution, 116.

[18] See PRO, T222/61, December 1942 and Anderson, 'Machinery of Government'.

[19] Danielz, 'Public Accountability'.

[20] Cm. 3638, Civil Service.

[21] Hague et al., Public Policy and Private Interests.

[22] Cole, 'Quangos'.

[23] Keeling, 'Beyond Ministerial Departments'.

[24] Goldston, 'Patronage in British Government'.

[25] Johnson, 'Quangos and the Structure', 384.

[26] The 1945 Anderson Committee had recommended that HM Treasury establish and maintain a register of bodies and make this available to all departments while also becoming responsible for advising departments about governance issues when the creation of a new body was being considered. By 1949, officials were questioning the value of the list and by 1951 it had been abandoned.

[27] Doig, 'Machinery of Government and the Growth'.

[28] Hood et al., 'So You Think You'.

[29] Stott, 'Snouts in the Trough'.

[30] Holland and Fallon, Quango Explosion; Holland, Quango, Quango, Quango; and Holland,

Governance of Quangos.

[31] Cole, 'Quangos', 339.

[32] PRO, PSD 11/1/2.

[33] House of Commons Hansard, 3 December 1979; see also 19 November 1984.

[34] Cm. 7797, Pliatzky Report.

[35] Hood, 'Axeperson, Spare That Quango', 102.

[36] Pliatzky, 'Quangos and Agencies', 557.

[37] Initially as NDPBs: Facts and Figures (1980 \& 1981) and from 1982 as Public Bodies.

[38] On the similarity between executive agencies and executive NDPBs see Cabinet Office, Better Government Services.

[39] van Thiel, Quangocratization.

[40] Cm. 3557, Governance of Public Bodies, para. 12.

[41] Hood, 'Politic of Quangocide'.

[42] Skelcher, 'Reforming the Quangos'.

[43] Flinders, 'Distributed Public Governance'.

[44] Cabinet Office, Opening Up Quangos, 10.

[45] Cabinet Office, Quangos.

[46] HC 209, Quangos.

[47] Ibid.

[48] Flinders, 'Devolution, Delegation and the Westminster Model'.

[49] See Flinders, Delegated Governance and the British State.

[50] Hood, 'Keeping the Centre Small' (The Times, 4 September 1969).

[51] HC 367, Mapping the Quango State.

[52] Cabinet Office, Better Government Services.

[53] Defra, Rural Development Review.

[54] Department of Health, Reconfiguring the Department.

[55] HM Government, Putting the Frontline First.

[56] Cameron, 'People Power'.

[57] Institute for Government, Read Before Burning.

[58] Institute for Government, Read Before Burning. See also Rutter and Nash, 'Quango Conundrum'.

[59] HM Government, Coalition, 16. 
[60] HC 313, Non-Departmental Public Bodies.

[61] On the specific boundaries of the review see Flinders and Skelcher, 'Shrinking the Quango State'.

[62] HC 505, Public Bodies Reform.

[63] Cabinet Office, Public Bodies Reform.

[64] The abolition or merger of some bodies did not require legislation while others were implemented using other statutory vehicles, such as the Education Bill and the Localism Bill.

[65] Cabinet Office, Public Bodies 2012, 8.

[66] Conservatives, Invitation to Join the Party, 8 and Cabinet Office, Written Ministerial Statement.

[67] National Audit Office, Reorganising Central Government Bodies.

[68] HM Treasury, 'Treasury Minutes'.

[69] Cabinet Office, Better Government Services.

[70] See, for example, Flinders, 'Act Smart'.

[71] Cabinet Office, Public Bodies 2012, 158 - 1599. Note that 13 'Veterans Advisory and Pensions Committees' were reviewed as part of a single triennial review. This means that twenty-two bodies were reviewed, but only nine triennial review reports completed.

[72] See Dommett,'Triennial Reviews and Public Body Reform'.

[73] Cameron, 'People Power'.

[74] A full list of spending controls can be found in Institute for Government, It Takes Two, 55 - 56.

[75] Institute for Government, It Takes Two, 17.

[76] Flinders, Delegated Governance and the British State, 147 - 152. [77] See note 70 above.

[78] Public Chairs' Forum, PCF Conference 2012.

[79] Hood, 'Politics of Quangocide'.

[80] Russell, Constitutional Odyssey.

[81] PASC, Smaller Government.

[82] Cabinet Office, Public Bodies 2012, 4.

[83] See Institute for Government, Strange Case.

\section{References}

Adam Smith Institute. Hunting of the Quango. London: Adam Smith Institute, 2009.

Anderson, John. 'The Machinery of Government.' Public Administration 24, no. 3 (1946): 147 - 156. Bagehot, Walter. The English Constitution. London: Chapman and Hall, 1867.

Bouckaert, G., and G. Peters. 'What is Available and What is Missing from the Study of Quangos?" In Unbundled Government: A Critical Analysis of the Global Trend to Agencies, Quangos and Contractualisation, edited by C. Pollitt, and C. Talbot, $22-50$. London: Routledge, 2004. Cabinet Office. Opening Up Quangos. London: Cabinet Office, 1997.

Cabinet Office. Quangos: Openning the Doors. London: Cabinet Office, 1998.

Cabinet Office. Better Government Services: Executive Agencies in the Twenty-First Century (Alexander Report). London: Cabinet Office, 2002.

Cabinet Office. Public Bodies Reform: Proposals for Change. London: Cabinet Office, 2011.

Cabinet Office. Written Ministerial Statement. London: Minister for the Cabinet Office, 15 December 2011. http://www.cabinetoffice.gov.uk/sites/default/files/resources/Written_Ministerial_Statement_Public_Bodies_Act_2011.pdf

Cabinet Office. Public Bodies 2012. London: Cabinet Office, 2012.

Cameron, David. People Power: Reforming Quangos, Speech. July 6 2009. http://www.conservatives. com/News/Speeches/2009/07/David_Cameron_People_Power_-_Reforming_Quangos.aspx

Centre for Policy Studies. School Quangos: A Blueprint for Abolition and Reform. London: Centre for Policy Studies, 2000.

Chapman, Richard A. The Civil Service Commission. London: Routledge, 2004.

Chester, Norman. 'Fringe Bodies, Quangos and All That.' Public Administration 57, no. 1 (1979):51 - 54.

Cm. 3557. The Governance of Public Bodies: A Progress Report. London: HMSO, 1997. Cm. 3638. The Civil Service (The Fulton Report). London: HMSO, 1968.

Cm. 7797. Report on Non-Departmental Public Bodies (The Pliatsky Report). London: HMSO, 1980. Cole, Michael. 'Quangos: The Debate of the 1970s in Britain.' Contemporary British History 19, no. 3 (2005): 321 - 353.

Conservatives. Invitation to Join the Party of Government: The Conservative Party Manifesto, 2010. http://www.conservatives.com/, /media/Files/Activist\%20Centre/Press\%20and\%20Policy/Manifestos/Manifesto2010

Craig, John. 'Whitehall Through the Centuries.' Public Administration 28, no. 2 (1950): 313 - 318. 
Daniel, G. H. 'Public Accountability of the Nationalised Industries.' Public Administration 38, no. 1 (1960): 27 - 35.

Defra. Rural Development Review (The Haskins Review). London: Defra, 2003.

Department of Health. Reconfiguring the Department of Health's Arm's Length Bodies (The Warner Review). London: Department of Health, 2004.

Doig, Alan. 'The Machinery of Government and the Growth of Governmental Bodies.' Public Administration 57, no. 3 (1979): $309-333$.

Dommett, Katharine. Triennial Reviews and Public Bodies Reform in the UK. January 2014. http://www.shrinkingthestate.org.uk

Finer, Herman. The Theory and Practice of Modern Government. London: Methuen, 1932.

Flinders, Matthew. 'The Enduring Centrality of Individual Ministerial Responsibility within the British Constitution.' Journal of Legislative Studies 6, no. 3 (2000): $73-91$.

Flinders, Matthew. 'Distributed Public Governance in Britain.' Public Administration 82, no. 4 (2004): 883 - 909.

Flinders, Matthew. Delegated Governance and the British State: Walking Without Order. Oxford: Oxford University Press, 2008.

Flinders, Matthew. 'Act Smart: Don't Abolish, Reform Quangos.' The Times, December 10 2009. Flinders, Matthew. 'Devolution, Delegation and the Westminster Model.' Commonwealth and Comparative Politics 49, no. 1 (2011): 1 - 28.

Flinders, Matthew, and C. Skelcher. 'Shrinking the Quango State: Five Challenges in Reforming Quangos.' Public Money \& Management 32, no. 5 (2012): $327-334$.

Goldston, Robin S. 'Patronage in British Government.' Parliamentary Affairs 30, no. 1 (1977): 80 - 96.

Greenleaf, William H. The British Political Tradition. London: Methuen, 1983.

Hague, D., W. Mackenzie, and A. Barker, eds. Public Policy and Private Interests. London: Macmillan, 1975.

Hanham, Harold J. The Nineteenth Century Constitution. Cambridge: Cambridge University Press, 1969.

HC 209. Quangos. Public Administration Select Committee. Sixth Report of Session 1998 - 99. London: HMSO, 1999.

HC 313. Non-Departmental Public Bodies. Hansard HC Debate vol. 511, col. 313, 2010.

HC 367. Mapping the Quango State. Public Administration Select Committee. Fifth Report of the Session 2000 - 2001. London: HMSO, 2000. HC 505. Public Bodies Reform, Hansard HC Debate vol. 516, col. 505.

HC 515. Public Bodies Reform, Hansard HC Debate vol. 516, col. 515, 2010.

HM Government. Report of the Machinery of Government Committee (The Haldane Report). London: HMSO, 1918.

HM Government. Putting the Front Line First: Smarter Government. London: HMSO, 2009. HM Government. The Coalition: Our Programme for Government. London: HMSO, 2010.

HM Treasury. Reducing Administrative Burdens: Effective Inspection and Enforcement (The Hampton Report). London: HMSO, 2005.

HM Treasury. Treasury Minutes: Government Responses on the Seventy Fifth, the Seventy Seventh, the Seventy Ninth to the Eighty First and the Eighty Third to the Eighty Eighth Reports of the Committee on Public Accounts. London: HMSO, 2012.

Holland, P. Quango, Quango, Quango. London: Adam Smith Institute, 1979.

Holland, P. The Governance of Quangos. London: Adam Smith Institute, 1981.

Holland, P., and M. Fallon. The Quango Explosion. London: Adam Smith Institute, 1978.

Hood, Christopher. 'Keeping the Centre Small: Explanations of Agency Type.' Political Studies 26, no. 1 (1978): 30 - 46.

Hood, C. 'The Politics of Quangocide.' Policy and Politics 8, no. 3 (1980): 247 - 265.

Hood, C. 'Axeperson, Spare that Quango.' In Big Government in Hard Times, edited by C. Hood, and M. Wright, 100 - 122. Oxford: Martin Robertson, 1981.

Hood, C., A. Dunsire, and S. Thompson. 'So You Think You Know What Government Departments Are ... ?" Public Administration Bulletin 27 (1978): 20 - 32. Hoogenboom, Ari A. Outlawing the Spoils. New York: Praeger, 1982.

Institute for Government. Read Before Burning: How to Increase the Effectiveness and Accountability of Quangos. London: Institute for Government, 2010.

Institute for Government. It Takes Two: How to Create Effective Relationships Between Government and Arm's Length Bodies. London: Institute for Government, 2012.

Institute for Government. The Strange Case of Non-Ministerial Departments. London: Institute for Government, 2013.

Jennings, Ivor. The British Constitution. Cambridge: Cambridge University Press, 1941. 
Johnson, Nevil. 'Quangos and the Structure of British Government.' Public Administration 57, no. 4 (1979): 379 - 395.

Keeling, Desmond. 'Quasi-Governmental Agencies.' Public Administration 54, no. 2 (1976):161 - 170.

National Audit Office. Reorganising Central Government Bodies. London: HMSO, 2012. Parris, Henry. Constitutional Bureaucracy. London: Allen and Unwin, 1969.

Pliatzky, Leo. 'Quangos and Agencies.' Public Administration 70, no. 4 (1992): 555 - 563.

Public Accounts Select Committee. Smaller Government: Shrinking the Quango State. London: HMSO, 2010.

Public Chairs' Forum. PCF Conference 2012: Key Points from Individual Sessions. London: Public Chairs' Forum, 2012.

http://www.publicchairsforum.org.uk/images/uploads/PCF_Annual_Conference_Summary.pdf

Robson, W. 'The Public Service.' The Political Quarterly 7, no. 2 (1936): 179 - 193.

Rutter, G., and T. Nash. 'The Quango Conundrum.' Political Quarterly 82, no. 1 (2011): 95 - 101. Russell, Peter H. Constitutional Odyssey. Toronto: University of Toronto Press, 1992.

Schaffer, B. 'The Idea of the Ministerial Department: Bentham, Mill and Bagehot.' Australian Journal of Politics and History 3, no. 1 (1957): 60 - 78.

Skelcher, Chris. 'Arm's Length Bodies: Why? What? Where To?' Paper to the Association of Chief Executives Conference, Wilton Park, 2013.

http://www.shrinkingthestate.org Skelcher, Chris. 'Reforming the Quangos.' Political Quarterly 69, no. 1 (1998): 41 - 47. Stott, Tony. 'Snouts in the Trough.' Parliamentary Affairs 48, no. 2 (1995): $323-340$.

Street, A. 'Quasi-Government Bodies Since 1918.' In British Government Since 1918, edited by G. Campion, 148 - 171. London: George Allen, 1950.

Toulmin Smith, Joshua. Government by Commission: Dangerous and Pernicious. London, 1849. van Thiel, Sandra. Quangocratization: Trends, Causes, Consequences. London: Ashgate, 2001. Willson, F. 'Ministries and Boards: Some Aspects of Administrative Development Since 1832.' Public Adminstration 33, no. 1 (1955): 43 - 58. 